\title{
Encourage Students' Affective Value in EFL Class THROUGH COOPERATIVE LEARNING
}

\author{
Rabi’ah, Achmad Baidawi, Ina Daril Hanna \\ State Islamic Institute of Madura (IAIN) Madura, Islamic University of Madura (UIM) \\ rabiah@iainmadura.ac.id, achmadbaidawi@iainmadura.ac.id, darilhanna88@gmail.com
}

\begin{abstract}
In this modern era, education is required not only to be able to create intelligent students but also to be able to create students who have good attitudes. The attitude that is needed when they are in the midst of society such as tolerance, respect for the opinions of others, mutual cooperation and the others. Considering that these attitudes have begun to decrease by the times and the advancement of civilization. Therefore, an educator is expected to be able to develop the ability of students not only in the cognitive domain but also in the affective domain. In this case, the lecturer as educator can give directly positive suggestion or creating a good teaching and learning that contain some valuable meanings. Implementing cooperative can covered both cognitive aspect and affective aspects. The method of this study is qualitative approach which descriptive design. This paper aims to describe what attitudes can be developed by applying cooperative learning methods and what strategies in cooperative learning can be done to encourage affective values of students. To Achieve the aims of this study, the researcher conducts the research in State Islamic Institute of Madura (IAIN Madura). The subject is the students of English Department in the first semester. The result showed that cooperative learning can improve respect, tolerate and solidarity value of the students. The model of cooperative learning that create those values is Number Head Together. Jigsaw, and Think Pair-share
\end{abstract}

Keywords: affective value, cooperative learning

\section{INTRODUCTION}

Recently, Indonesia is plagued by a crisis of morals in which disputes, mutilation and selfrighteousness have plagued all sectors of human life, including the world of education. The harmony between religions is disturbed by the existence of radical ideology. Even the harmony between Moslems is disturbed by the existence of different faith. It must be immediately addressed. In this case the world of education as a place to produce knowledgeable and good personality people must be able to provide solutions to these problems. The students should be taught Islamic moderation. So that the goal of national education is truly realized. In line with this statement Alvionita and Arifmiboy stated that the general orientation of the 2013 Curriculum is to increase and improve both soft skills and hard skills which include some competencies like attitudes, skills, and knowledge (Alvionita \& Arifmiboy, 2021). Especially an educator, in this case it is requested not only to create students who are intellectually smart students, but also have good attitude. In other words, the process of teaching and learning in the class should cover both cognitive and affective domains. The term "affect" refers to emotion or feeling, the aspects of our emotional side of human behavior, and it may be juxtaposed to the cognitive side. Richards \& Schmidt (2002:169) in Sugirin define affective domain as objectives that have as their purpose the development of students' attitudes, feelings, and values (Sugirin, 2010). While according to Boom (Walter, 1987) in Rambaugh stated that affective doimain includes objectives that describe a change in interest, attitude, and value and the development of appreciations and adequate adjustment. Based on humanistic psychology, learners should be treated as the whole person with both intellectual and emotional needs (Rumbaugh, n.d.).

From the objectives above, actually where the direction of Indonesian education is clear. But in practice, it has not been realized or reached. Lecturers as implementers in learning activities not only play a role in transferring knowledge but also as educators who instill good values to students or directing students to have good manners and courtesy. According to Dewey that is cited by Syahraini Tambak stated the classroom should mirror the large society and be a laboratory for real-life learning (Tambak, 2017).

Concerning such conditions above, it is necessary to think of alternatives or ways that can be done by lecturers in creating students who are not only reliable in science but also have good morals. One way that can be done by lecturers is by applying the cooperative learning method. Where this method students learn in groups to achieve the objectives of the learning. But today the use of this method is only used to create a competitive spirit among students. Looking for who is the best among the other 
groups. not in the realm of exploring values of attitudes such as respecting the opinions of others, correlating to differences, and how students interact with each other in the group.

Cooperative learning is a model of group learning that has certain rules. According to Wena the basic principle of cooperative learning is that students form small groups and teach each other to achieve common goals, even in this learning smart students teach students who are less clever students without feeling disadvantaged (Wena, 2011). Cooperative learning is also a model that prioritizes cooperation among students to achieve shared goals. Basically, the cooperative learning method is in line with human nature as a social creature who needs others.

According to Johnson et al (2011). that cited by Singh and Agrawal cooperative learning is an educational tool in which small groups of students work together to increase individual, as well as, group member learning. Cooperative learning exists when students work together to achieve joint learning goals (Singh \& Agrawal, 2011).

Positive dependence on cooperative learning will motivate students to take responsibility for the success of their learning process. In this case, students will learn to help their weak friends and learn to respect one another. Besides that, they will respect the efforts of each member of the group. Students will work well together as a consequence to ensure that each participant in the group understands the material they are discussing. The ability to influence each other in making reasons and conclusions, social modeling, social support, and suppressing each other's ego is the impact of cooperative learning methods. In cooperative learning students are required to have interaction skills such as submitting opinions, listening to the opinions of friends, displaying leadership, compromise, negotiation and classification on a regular basis to complete their tasks.

In line with the cooperative understanding above, the Qur'an has been explained as contained in Surah al-Maidah verse 2

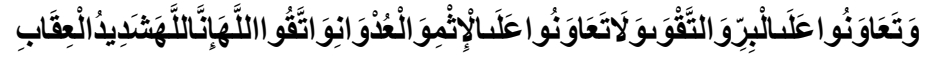

And cooperate in righteousness and piety, but do not cooperate in sin and aggression. And fear Allah; indeed, Allah is severe a penalty (Q.S Al-Maidah:2) (http://www.alquranenglish.com/quransurah-al-maidah-2-qs-5-2-in-arabic-and-english translation).

Similar research has been done by Muslih. He found that Cooperative Learning has some advantages not only in boosting student academic achievement, but can also encourage the social aspects of treatment such as respecting others, empathy with others, cooperate with others and reduce the various negative aspects of competition, as well as able to give impressions on some other positive behaviors (Muslih, n.d.). Most of the researches on the issue have concluded that student's attitude is an integral part of learning and that it should, therefore, become an essential component of second or foreign language learning pedagogy (Getie, 2020).

Another research that also studied about improving students'affective value through cooperative learning is done by Martati. He found that one of the modelsof learning which includes a learning process that reflects value moral is cooperative learning. Because in student cooperative learning learn to respect friends and work together in small groups. Furthermore, Slavin in Martati stated that cooperative learning has many different forms (types), but all of them involve students working in small groups or teams helping each other in learning academic material. In the cooperative learning model, moral value education can be found, namely: students learn something, there is respect for groups, individual responsibility, equal opportunity to succeed, learning is fun, working in pairs, working in groups, and so on (Martati, 2018).

\section{MATERIALS AND METHODS}

This study is a qualitative approach. It uses decriptive design and it is classified into a case study. Bogdan and Biklen in Wafi, elaborate that a case study is a detailed examination of one setting, or one single depository, or one particular event (Wafi, 2019). Where the goal is to describe the researchers' experiences in encourage students' affective value through cooperative learning. The scopes of this study were on implementing cooperative learning method to encourage students' affective value. To reach the goal the researchers is applying cooperative method to promote students' affective value. The researchers conducts the research in State Islamic Institute of MADURA (IAIN MADURA) especially in the first semester of students of English department. The number of the subject is 36 students. Observation and interview are used as instrument. Observation is a technique that observes the students' or subjects' attitude (Sugiono, 2012). While Agrosino, M.V in Latief defined as a process of fieldwork by which people interacting in thier natural setting are studied so that their behavior and words can be 
put into their proper context (Latief, 2012). While interview Borg et all in Latief (2012) defined interview is a data-gathering instrument that involves direct verbal interaction between individuals (Latief, 2012). In this case, the researchers uses unstructured interview. It means that the interview is not planned in detail ahead of time; the researchers asks a question as the opportunity arise and listens closely and uses the subjects' responses to decide on the next question.

Some steps were done in doing the research. The first is preparation, in this step the researcher making a lesson plan, making an observation sheet, making an interview guide line. After all the instruments to got the data were done then the researcher conducted the teaching and learning process by using some cooperative learning. To gain the data the researchers did some activities. For the first, the researchers conduct the teaching and learning process by implementing cooperative method. Here, the researchers uses various technique or type in cooperative learning namelly jigsaw, NHT and think pairshare. The second, the researchers is doing observation while the students work in a group. The researchers observes how the students interact each other and how the students' attitudes in a group. The researchers used an observation sheet to observe the activity.In the teaching and learning process, the researcher observed the phenomena that appear in the class. The researcher tick the affective value that come up during teaching and learning process.

The third, the researchers is asking some question related with the study. In this case, the researchers conducts an interview. Here, the researcher used an interview guide line to interview the students. All of the students in every group were asked about what attitude which is treated by implemented cooperative learning. To answer the second question of this study the researchers was implementing the various techniques in cooperative learning and then analyses them. The last step is presenting the data. Here the researchers presents the result of her research after conducting some various techniques in gaining the data. In presenting the data the researchers shows the data in every meeting result. In analyzing the data, the three steps were done. They are data condensation, data selection, and data display. Data condensation means reducing unsuitable data that got from interviews and questionnaires. This step was followed by data selection. In this step, after data is reduced the researchers choose the data that answer the two research objectives only. The last step was presenting the data clearly and systematically.

\section{RESULTS AND DISCUSSION}

The researchers conducted the research during three meetings. In each meeting the researchers implemented different techniques or types of cooperative learning. As stated before, that the aim is to encourage students' affective value. Here, the researchers presented the data in every meeting. In the first meeting, the researchers conducted the teaching and learning process by implementing the Jigsaw technique. The result showed that while discussing the lesson the students presented a good interaction among students. They discussed the topic nicely. The leader explained the topic. It trains the students' responsibility. While the member of the group was showing a good attention. They took a part in group discussion equally. It indicates that they respect to his or her friend. Besides that, the researchers found empathy value. It occurs when the capable student helped the others who are lower. This data was gained through observation.

While for interview result showed that for about $35 \%$ students stated that the activity could improve students respect each other when they face diverification of opinion. $36 \%$ students stated that jigsaw technique could encourage students' mutual cooperation. The rest stated that the activity could improve students' responsibility. In line with this finding Trianto that cited by Rijal stated that in cooperative learning students are not only as learners but aslo as teachers who give information or explain the material to their friends in their group (Rijal, 2015).

In the second meeting, the researcher taught the students by using Number Head Together (NHT) technique. This technique includes cooperative learning. The result of observation showed that most of the students in a group were enthusiastic in discussing the topic. They cooperated happily. The students became confident to deliver their opinion. They tried to receive the differences among them. They tried to take conclusion about the lesson wisely. In the NHT technique, the students were trained to be hard workers. It happened when they were eager to finish their work. While for the result of the interview showed that $55 \%$ of the students agreed that the NHT technique increased their tolerance among the students. It occurred when they had different ideas or opinions. $30 \%$ of students said that the NHT technique could increase their motivation in solving the problem. The rest of the students for about $15 \%$ said that this technique could increase their competitive value. 
In the third meeting, the researchers conducted the teaching and learning process by setting the students in face-to-face form. It is called by think-pair-share. Think pair share is a collaborative learning strategy where students work together to solve a problem or answer a question about an assigned reading. Think pair share promte students to think together with their patner in group to solve their work. Think pair-share support higher-order thinking (Sumarni, 2016). Therefore, the result of observation indicated that treating the student with a think-pair-share technique could improve students' affective value such as solidarity, helpful and the most important the students have experienced how to interact with other people. This is supported by Rosita and Leonard (2015) they argued that two heads are better than one head, which can be interpreted that with the cooperation, students can develop selfconfidence, add life experiences and enhance social interaction that will help students to live in their real life in the future (Rosita \& Leonard, 2015).

For the result of the interview, the students delivered that they enjoyed the learning process because they could share their idea each other. Beside that, the students also had the same opportunity to deliver their idea or statement. It meant that the students could participate in learning equally.

Instilling the values of goodness or in other word fostering students' attitude values can be done directly and indirectly. Directly is giving advice, provide direction in the form of words. Whereas, the indirect way is by giving examples or by applying methods that can encourage the students' affective value. In this case the researchers implement cooperative learning especially jigsaw, HNT, and thinkpair-share to encourage students' affective value. From the result above, it can be summarized that jigsaw can increase students' responsibility, cooperation, and respect. This strategy makes students more active in participating learning process. In line with this, Rusman (2012) stated that there are two advantages using cooperative learning; they learn to understand or solve the problem and also help each other in their small group (Rusman, 2012).

In line with Islamic moderation, those effective value is really needed by the students. For example; respect, this affective value will help students when they face the diversity of opinion, people, and religion. The students can cooperate with other people without looking at the religion, ethnic and tribe.

In Number Head Together (NHT) students learn to tolerate the opinions of his/her friend in the group. The students is understanding each other during the discussion. Cooperative learning offers a pleasant learning situation for all students, all students have equal opportunity, competition is amended as friendship, the spirit of cooperation and participation is reinforced, and all students are entitled to be thoughtful and creative (Laguador, 2014). This affective value is crucial for the students' concerning Indonesia has six religions as a faith of Indonesian citizens. The students have tobe used to with diversity.

The last is in think-pair-share. The students learn to be wise and have a good solidarity between the students. It is also needed by the students when they are in real life. They should be wise in deciding the problem.

From the explanation above, it can be concluded that the first research problem of this study has been answered. It means that there are many affective's values that can be developed through cooperative learning. And for the second research problem is also answered. In this case, jigsaw, NHT, and think-pair-share can encourage students' affective value. There are some principles of cooperative learning that proposed by Jacobs are (a) Heterogeneous Grouping, (b) Collaborative Skills, (c) Group Autonomy, (d) Simultaneous Interaction, (e) Equal Participation, (f) Individual Accountability, (g) Positive Interdependence, (h) Cooperation as a Value (Baidawi et al., 2021). Some of those principles can be build by applying some techniques in cooperative learning as researchers did in their reserach. Think pair share promate the students to act wisely when atking decition. While Head Number Together treat students tobe tolerant in their life. the lats is jigsaw. Jigsaw encourages the students in equal participation.

\section{CONCLUSION}

Based on the research finding and theories, the researcher concluded some points concerning with this study. The first cooperative learning such as Jigsaw, Number Head Together and Think pair-share could encourage students' affective value. For instance; responsibility, respect, empathy and helpful. These values appeared in the Jigsaw teachnique. Whereas for Number Head Together could encourage students' motivation in learning and competitive value.

The second, think-pair-share type could increase the students social interaction and generous value. It is because they could share their knowledge equally. Think pair-share also created an enjoyable condition for the students because they could discuss the lesson in face-to-face form. 
Therefore, teaching and learning process is not only emphasized in the cognitive domain but also in affective domain. So that the students will be ready to associate with the society after graduating from university. They can appreciate the diversity of opinion, religion, tribe, and ethnicity. They can live peacefully. It is suitable with the principle of Islamic moderation that is justice and balance.

The last, the researcher suggested for all educators to use cooperative learning to encourage students not only for the cognitive domain but also affective domain. Cooperative learning is proper for developing both of them.

\section{REFERENCES}

Alquran English. 'Quran Surah Al Maidah 2 (QS 5: 2) in Arabic and English Translation', 1 July 2009. http://www.alquranenglish.com/quran-surah-al-maidah-2-qs-5-2-in-arabic-and-englishtranslation.

Alvionita, S., \& Arifmiboy, A. (2021). Character Education Values on Dialogue in English Textbook Entitle Bahasa Inggris Think Globally Act Locally. New Language Dimensions, 1(2), Article 2. https://journal.unesa.ac.id/index.php/nld/article/view/11090

Baidawi, A., Rabi'ah, R., \& Wafi, A. (2021). Instilling Character Values Using Jigsaw in Teaching Grammar. Journal of English Education and Teaching, 5(3), 425-435. https://doi.org/10.33369/jeet.5.3.425-435

Getie, A. S. (2020). Factors affecting the attitudes of students towards learning English as a foreign language. Cogent Education, 7(1), 1738184. https://doi.org/10.1080/2331186X.2020.1738184

Laguador, J. M. (2014). COOPERATIVE LEARNING APPROACH IN AN OUTCOMES-BASED ENVIRONMENT. International Journal of Social Sciences, 2(2), 11.

Latief, M. A. (2012). Research Methods on Language Learning an Introduction. UM Press.

Martati, B. (2018). Model Pembelajaran Kooperatif Untuk Menumbuhkan Nilai Moral Siswa Sekolah Dasar. ELSE (Elementary School Education Journal) : Jurnal Pendidikan Dan Pembelajaran Sekolah Dasar, 2. https://doi.org/10.30651/else.v2i1.1405

Muslih, M. (n.d.). PEMBELAJARAN MORAL MELALUI PEMBELAJARAN KOOPERATIF. 15.

Rijal, S. (2015). Student Teams Achievement Division (STAD) at English Language Teaching. Wacana Didaktika, 3(2), 122-127. https://doi.org/10.31102/wacanadidaktika.3.2.122-127

Rosita, I., \& Leonard, L. (2015). Meningkatkan Kerja Sama Siswa Melalui Pembelajaran Kooperatif Tipe Think Pair Share. Formatif: Jurnal Ilmiah Pendidikan MIPA, 3(1). https://doi.org/10.30998/formatif.v3i1.108

Rumbaugh, W. (n.d.). Affective Domain Applications in Standards-Based Education. 163.

Rusman, R. (2012). Model-Model Pembelajaran; Mengembangkan Profesionalisme Guru. PT Raja Grafido Persada.

Singh, Y. P., \& Agrawal, A. (2011). INTRODUCTION TO CO-OPERATIVE LEARNING. Indian Streams Research Journal, 10.

Sugiono. (2012). Metode Penelitian Kuantitatf, Kualitatif Dan R\&D. Alfabeta.

Sugirin, S. (2010). AFFECTIVE DOMAIN DEVELOPMENT: REALITY AND EXPECTATION. Jurnal Cakrawala Pendidikan, 3(3), Article 3. https://doi.org/10.21831/cp.v3i3.357

Sumarni, S. (2016). Think Pair Share Effect of Understanding the Concept and Achievement. Proceeding of the International Conference on Teacher Training and Education, 2(1), 783-787.

Tambak, S. (2017). Metode Cooperative Learning dalam Pembelajaran Pendidikan Agama Islam. AlHikmah: Jurnal Agama dan Ilmu Pengetahuan, 14(1), 1-17. https://doi.org/10.25299/alhikmah:jaip.2017.vol14(1).1526

Wafi, A. (2019). Using Games to Improve Students' Active Involvement in the Learning of English Syntax at IAIN Madura: An Autonomous Learning. OKARA: Jurnal Bahasa Dan Sastra, 13(1), 107. https://doi.org/10.19105/ojbs.v13i1.2256

Wena, W. (2011). Strategi Pembelajaran Inovatif Kontemporer. Bumi Aksara. 
